Historic, archived document

Do not assume content reflects current scientific knowledge, policies, or practices. 

The Leading Fruit Grawers in Every Fruit Grawing Sectian Prefer Harrisan Grawn Fruit Trees and Fruit Plants

\section{New Lower Prices}

Now Every Planter Can Buy Dependable True to Name Harrison Grown Fruit Trees at Prices No Higher Than the Ordinary Tree.

The World's Foremost Fruit Variety Identification Specialists Have Examined Harrison Grown Trees and Pronounced Them True To Name.

In addition to carefully selecting the propagating wrood from bearing trees of superior strains we have also employed the services of Dr. J. K. Shaw, Research
Professor of Pomology of Massachusetts State College, Amherst, Mass., and of Dr. W. H. Upshall of the Vineland Ontario Canada Experimental Station. These two alists and they have pronounced our trees true to name. SAVE DISAPPOINTMENT

PLANT HARRISONS' TREES

THE REASONS BACK OF GROWING SUPERIOR STOCK

A-Our orcanization has over 55 vears experience.

B-Every step in growing under the personal supervision of the Harrison brothers.

C-One hundred thousand trees in our own orchards from which our propagating planis are selected.

D-Use of modern methods for planting, cultivating and digging.

E-Over 5000 acres of various types of soil.

F-Ideal soil and climatic conditions.

G-Cooperation with leading horliculturists and experimsntal stations all over the world.

We Offer The Most Outstanding New Late Ripening Yellow Freestone Peach Ever Discovered

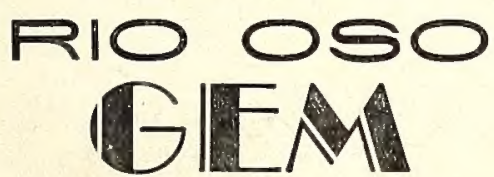

Worlds Largest Peach

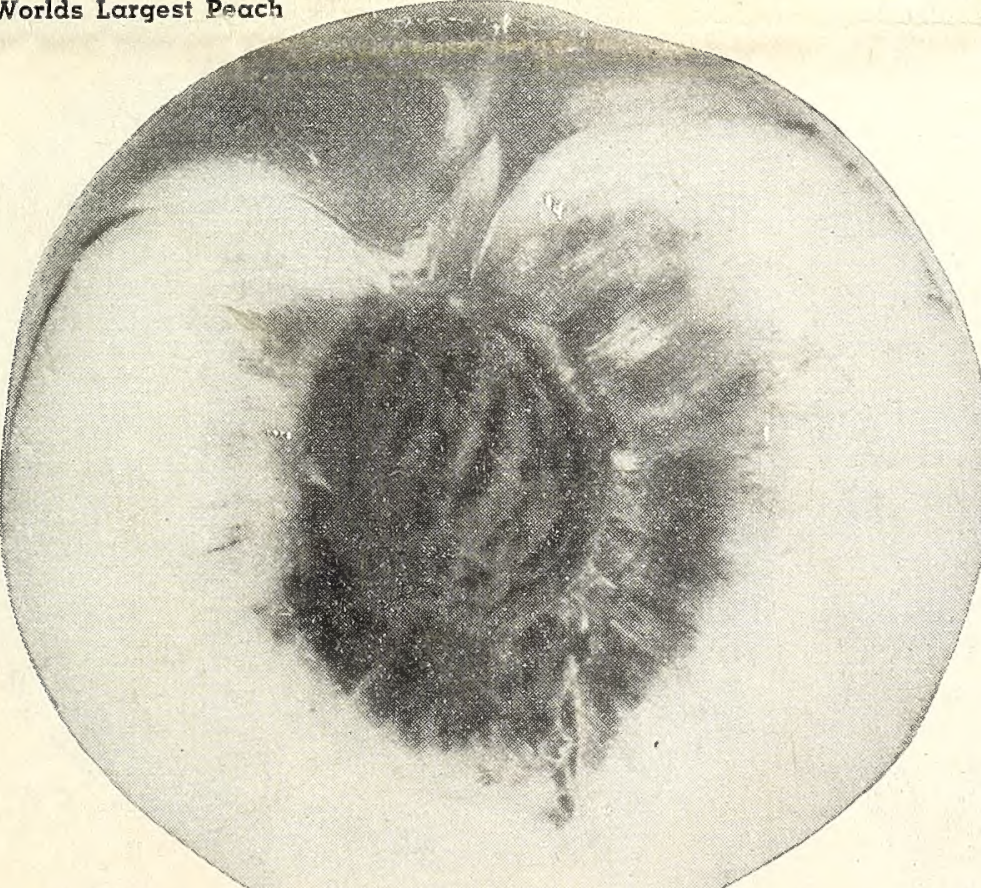

U. S. Plant Patent

See Next Page

\section{Because They Are}

* Absolutely True to Name

Healthy - Vigorous

Disease free

Hardy

Broperly hardened off before digging

Propagaied from bearing trees of selected siroins

Come into bearing earlier

Yield bigcer crops of betier fruits

Have larger roois

Take hold quiclely in new locations

The best irees for less money

\section{Fifty Five Years of Progress}

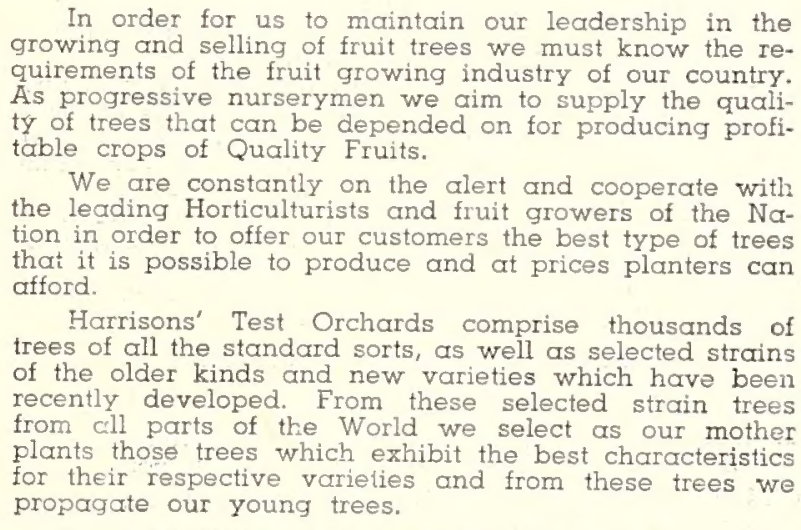

HARRISONS' TREES SUCCEED

NORTH - EAST — SOUTH - WEST

Save Money - Play safe with your investment-Buy Harrison grown superior quality Fruit Trees

Dependable-True To Name

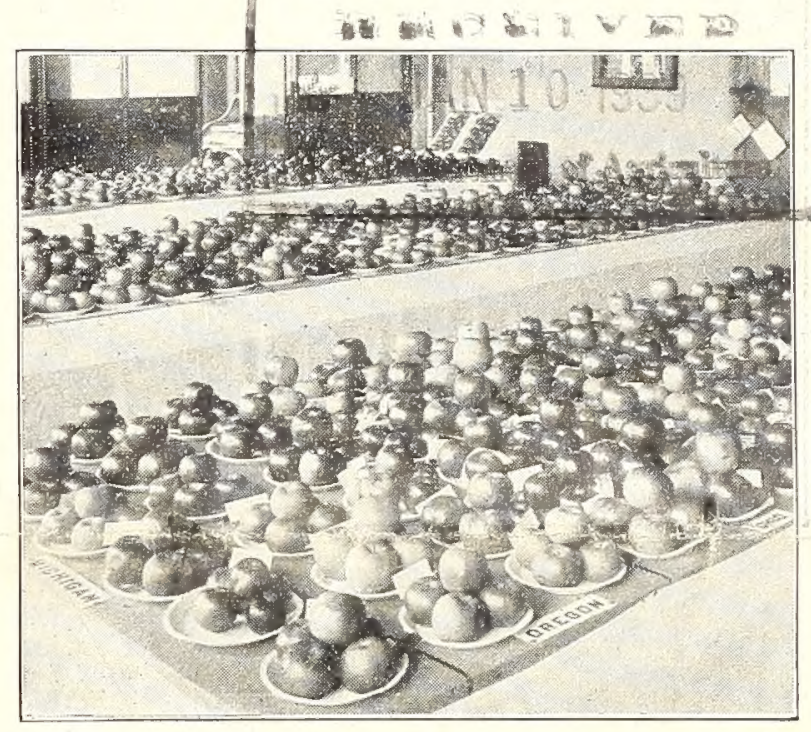

Harrisons' Fruit Trees Bear Prize Winning Fruits

\section{COME TO BERLIN SEE FOR YOURSELF}

* Largest acreage of young apple and peach trees in the world.

Mammoth packing houses for packing fruit and trees.

* Most extensive planting of apple and peach or chards in the East.

Hundreds of acres of ornamentals.

(The Harrison Bros. Extend to Everyone Interest(ed In Horticulture a Personal Invitation to Visit) Dress Up Your Home Grounds With Harrison Grown Ornamentals

Did you ever realize what a few dollars invested in vergreens, shade trees, shrubs, roses, etc. will add to the value of your property? We grow these items by tho hundreds of thousands and at our low prices this season we urge every home owner to take advantage of the oppurtunity and make his planting now. On page in high quality ornamentals that will succeed every-

\section{Plant Now.}

Do Not Let A Few Light Frosts And Freezes Delay Your Plonting This Year. Fall and winter planted stock has one great advantage over spring planted stock in that it wiil
start to grow earlier in the spring. It is a well known fact that the roots on all trees, plants and shrubs grow during the winter time and get well established before the late spring droughts.

It is a mistaken idea among many planters that nursery stock should be planted early in the fall safely planted. After a few cold periods and before the ground is frozen is the ideal time for plant ing deciduous stock.

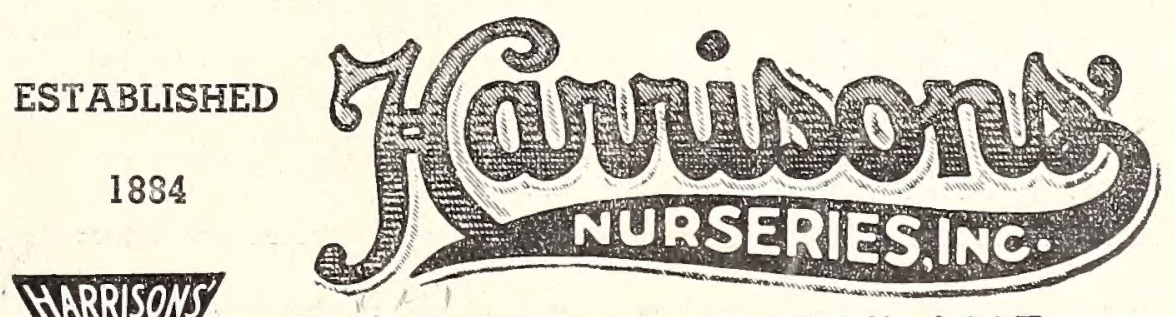

BERLIN, MARYLAND IARGEST GROWERS OF FRUIT TREES IN THE WORLD.
5000

ACRES

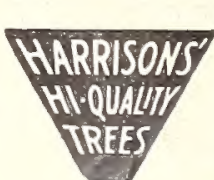




\section{Plant Peaches For Quick Profits}

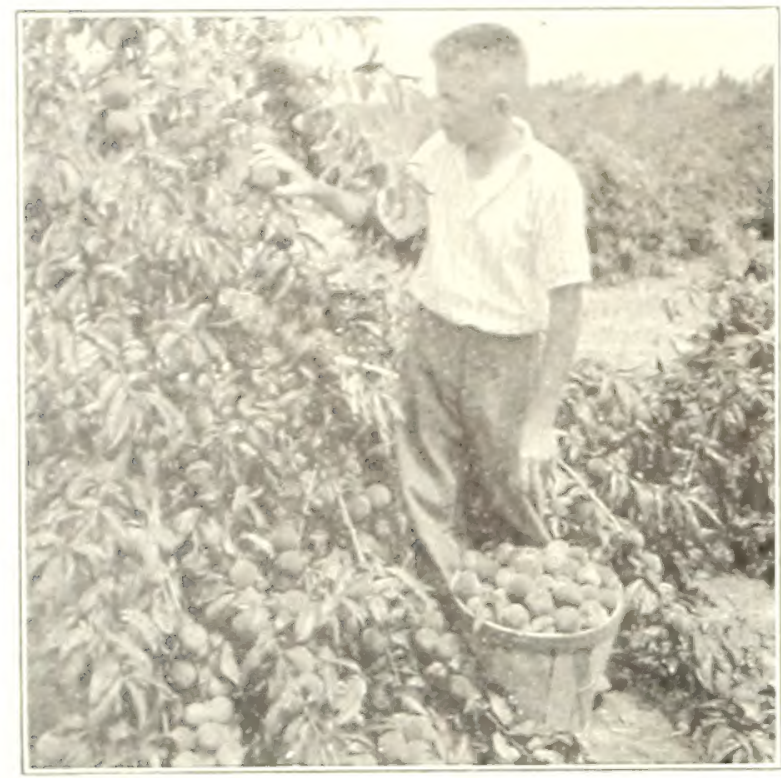

Hiley Bears Bumper Crops.

VERY EARLY VARIETIES

ADMIRAL DEWEY.

BUTTEKCUP.

EARLY ROSE.

GREENSBORO

MT. ROSE.

RED BIRD CLING.

UNEEDA.

CARMAN.

CUMBERLAND.

DELICIOUS.

EARLY HILEY

ECLIPSE.

GOLDEW JUIBILEE.

\section{Rio Oso Gem}

MAMMOTH SIZE - COLORS ALL OVER
DEEORE RIPENING - RIPENS TWO WEEKS
AFTER ELBERTA

PRICES OF RIO OSO GEM
HARRISONS HI QUALITY TREES DUE TO THEIR METHOD OF PROPAGATION EN. ABLES YOU TO GROW THE FINEST CROPS IN THE LEAST POSSIBLE TIME.

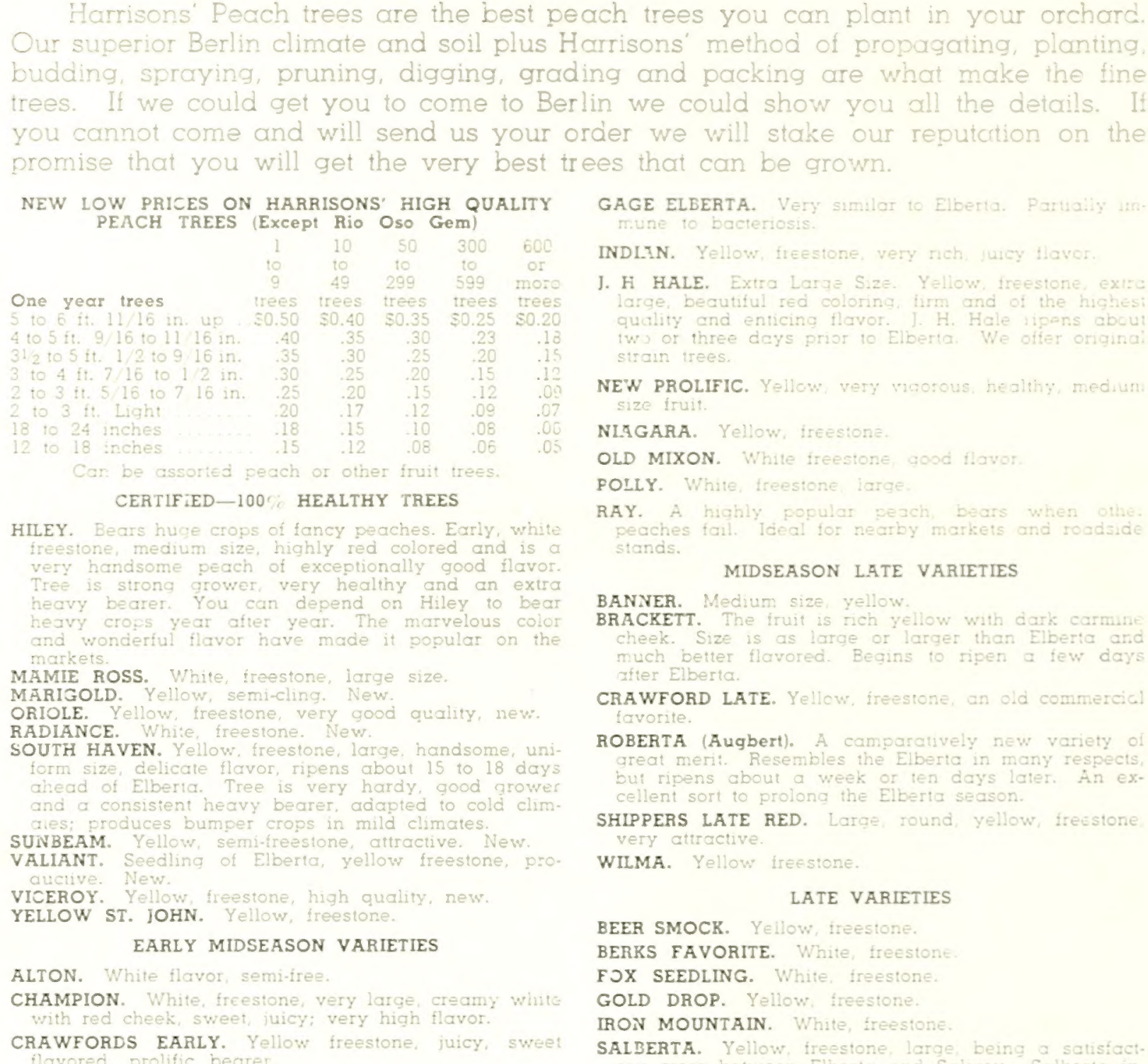

NEW LOW PRICES ON HARRISONS HIGH QUALITY GAGE ELEERTA.

HILEY.

BACKETT.
cheek.

CRAWFORD LATE.
fCVOITE.
ROBERTA (Augbert).

CRAWFORD LATE.
fCVOITE.
ROBERTA (Augbert). \\ RAY$$
\text { Hate. }
$$

\section{MIDSEASON LATE VARIETIES}

SHIPPERS LATE RED.

WILMA.

BEER SMOCK.

BERKS FAVORITE

FOX SEEDLING.

GOLD DROP.

IRON MOUNTAIN

SALBERTA.

\section{LATE VARIETIES}

FAIR BEAUTY.

KALE HAVEN

ROCHESTER.

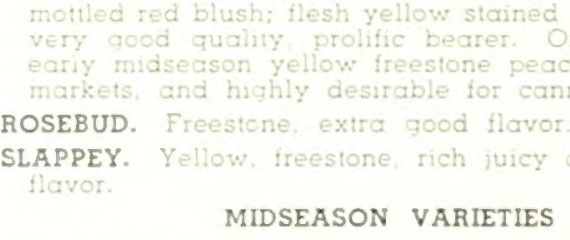

BELLE OF GEORGIA (Belle).

EILLMEYER.

ELBERTA

KRUMMELS

\section{VERY LATE VARIETIES}

SALWEY.

WHITE HEATH CLING

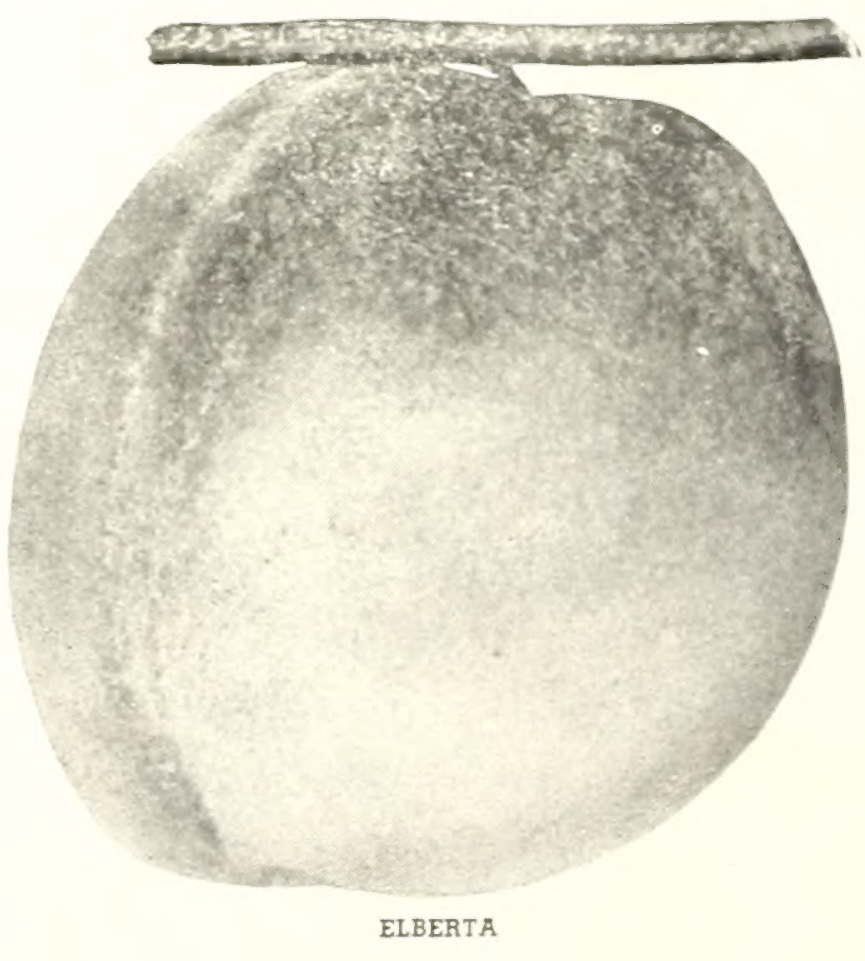




\section{New Lower Prices}

on Harrisons' Selected Strain True-To-Name Apple Trees---The Finest That Can Be Grown
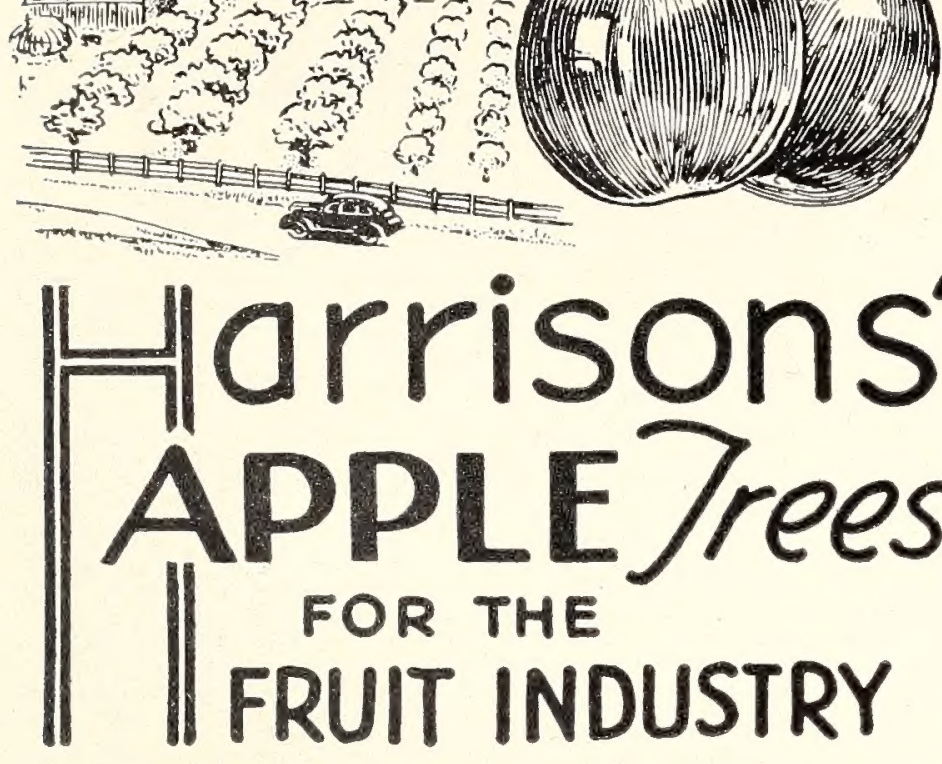

ON HARRISON
APPLE TREES

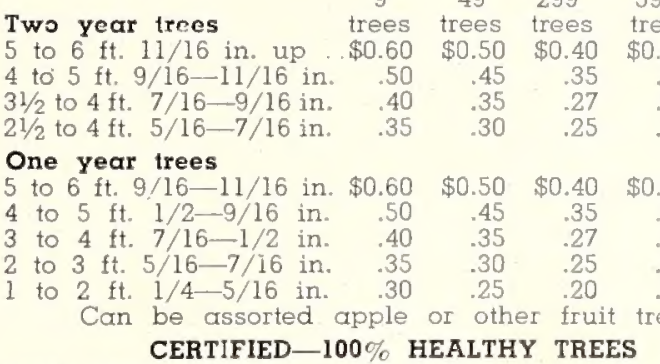

MAMMOTH GRIMES.

MAGNUM BONUM.

\begin{abstract}
We offer to the apple planter this season the fines lot of one and two year apple trees we have ever ing orchards of superior strains on whole root seedlings. During the past fifty years Harrison grown apple trees have been planted in every state in the Union as well as several foreign countries and At the present time we have mare of the improved and better strains of apples in our nursery than any other concern in America. With pay you to replant your old orchard or start a new one. SUMMER APPLES
\end{abstract}

year trees only).
CARLTON. Resembles red Astrachan, new (1 year trees DUCHESS (Duchess of Oldenburg). Large, red striped, EARLY HARVEST. Medium size, yellow.

EARLY MCINTOSH. Red, attractive, good size, flesł White, fine, tender, juicy and fine flavor, being simi-
lar to McIntosh Red. Tree vigorous, hardy, healthy LARGE TRANSPARENT (LODI). An improved Yellow MELBK. A seedling of McIntosh. Good size, early. (1 MILTON. Fruit a beautiful pinkish red with tender, crisp, RED DUCHESS. Solid red early coloring strain of DuRED JUNE (CAROLINA). Medium size, red. (I yr. trees STARR. Large, yellowish smooth skin; sometimes marked with a faint blush and numerous russet dots; flesh SWEET BOUGH. Pale yellow, large, tender, sweet. SPITZENBURG.

SUMMER RAMBO. Large, yellowish green, splashed with

large size, bright good quality. Its bright, attractive red coloring, with Early Red a pop
WIISON RED IUINE.

YELLOW TRANSPARENT

verying rurposes variety of any merit on the markets.
AUTUMN APPLES

FAMEUSE (Sn GRIMES GOLDEN. Medium size, yellow, heavy bearer and Virginia. The best pollenizer for Stayman Wine JONATHAN

flavored.

treeper and an excellent shipper. Tre produces big crops every year. Popular bushel and its attractive red appearance and tine flavor.
KEETOSH. A seedling of McIntosh. Canadian origin KING DAVID. Very dark red, medium size, good flavor KENDALL. A McIntosh seedling, very handsome. Same

LOBO. Similar to McIntosh but colors ecrlier

MAIDENS BLUSH. Large, red blush.

ED. An exceedingly valuable hardy, attrac when ripe. Flesh white, fine tender, juicy, sub-aci and refreshing, and generally conp splendid appea ance, which sells it on sight.
NORTHWESTERN GREENING.

OGDEN.

ORLEANS.

RED GRA VENSTEIN.

Gravenstein, with better and higher red

red.

WEALTHY. Mediu

YELLOW DELICIOUS.

$$
\begin{aligned}
& \text { cided "delicious" } \\
& \text { has a remarkabl } \\
& \text { for eating during }
\end{aligned}
$$$$
\text { September and I }
$$

famous Delicious.

\section{WINTER APPLES}

ARKANSAS BLACK.

trees OnlY).
ALBEMARLE PIPPIN

bed and
BALDWIN.

New York, Northern Pennsylvania, the New England

CORTLAND. Red, new variety. Cross between McIntosi

DELICIOUS. Red latg.

priced apples

GALLIA BEAUTY. Davis). Bright red, medium to largo

in every respect, except its earlier coloring qualities.

LOWRY. Beautiful mahogany red, very popular in Vir

ginia.

ripens later.
MEDINA. Delicious type, slightly larger, recommended

MAMMOTH BLACK TWIG

NEWFANE. Delicious type,

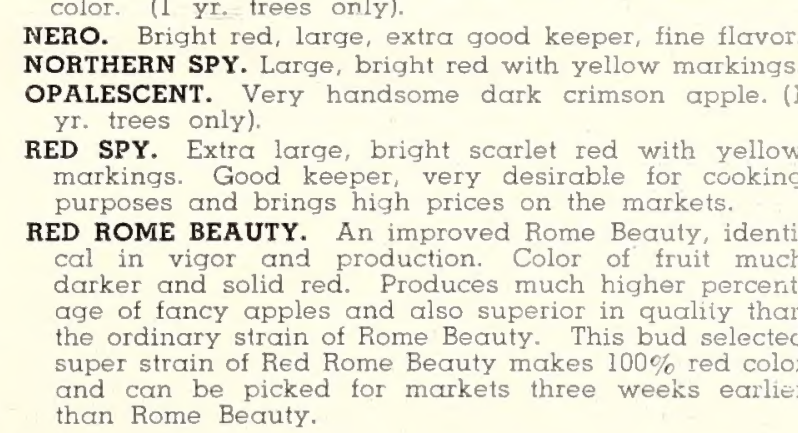

\section{Harrisons' Triple--Red Delicious}

A REAL MONEY-MAKER FOR GROWERS EVERYWHEKE

This Apple was introduced by us several seasons ag and since introduced it has been bought and fruited $b$
the tens of thousands by leading fruit growers througt out the country. It is a "bud sport" of pronounced sup erior merits. Being triple

It has all the fine qualities of the regular Delicious, with the exception that in

than the ordinary strain. It is conceded to be the most beautiful of all apples

local and city markets

you wish to plant a thousand or if you have room fo full value.
RED YORKING

ROXBURY RUSSET.

RHODE ISLAND GREENING.

ROME BEAUTY

STAYMAN WINESAP.

START.

SWEET DELICIOUS.

TURLEY.

TWENTY OUNCE.

WOLF RIVER.

WINESAP.

WINTER BANANA. the best and longest keepers.

WAGENER.

WINiER RAMBO.

YELLOW BELLEFLOWER,

YELLOW BELLEFLOWER IMPROVED.

YORI IMPERIAL.

\section{CRAB APPLES}

HYSLOP CRAB.

TRANSCENDENT.

YOUNG AMERICA CRAB.
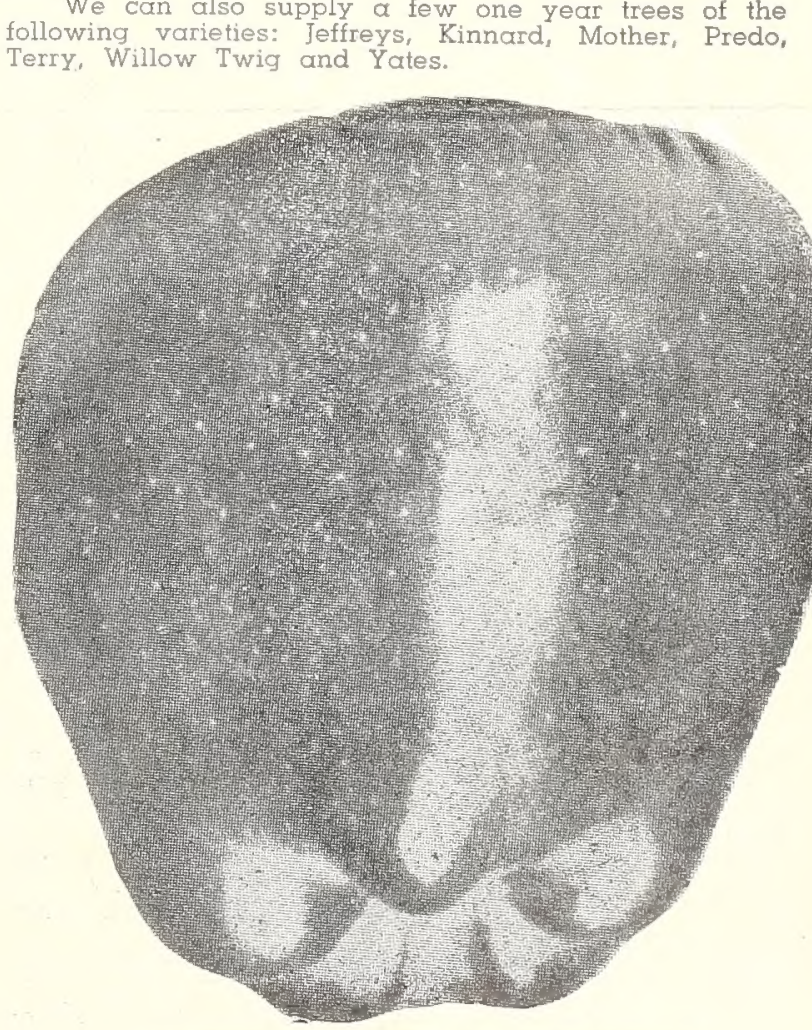

HARRISONS' TRIPLE-RED DELICIOUS 


\section{Harrison's Hi-Quality Fruit Trees and Grape Vines}

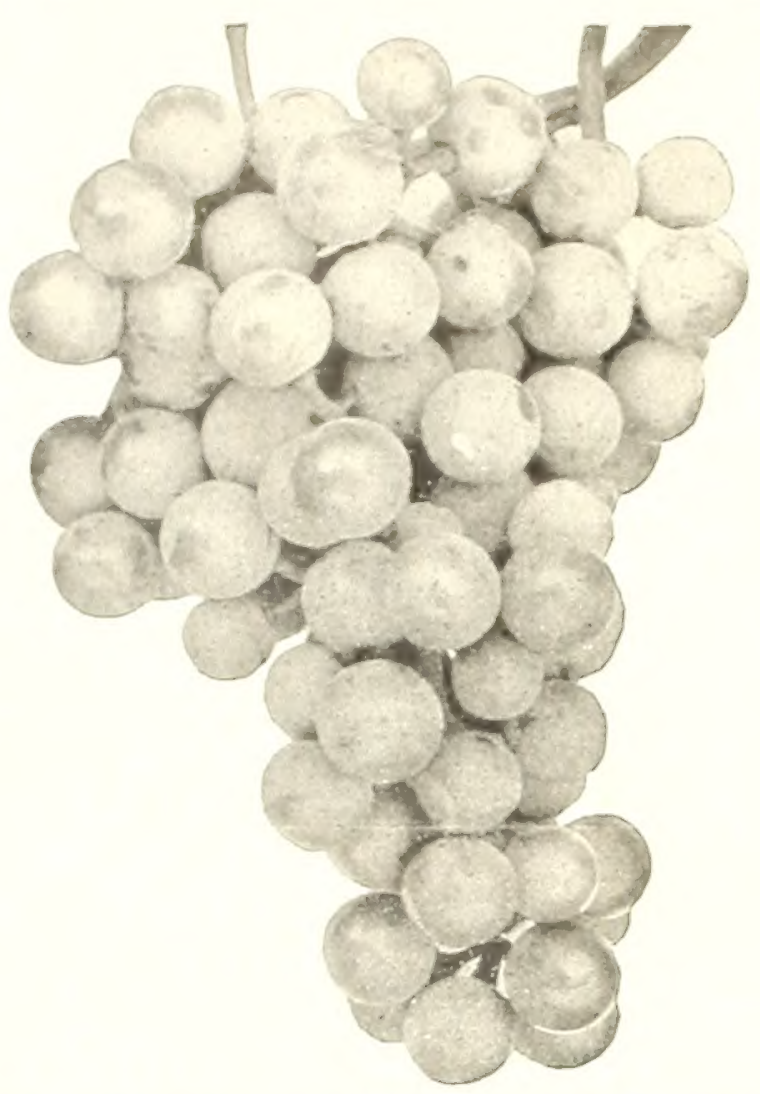

HARRIऽONS' HI-QUALITY GRAPE VINES A SPECIALTY WITH US

Black Grs
CLINTON.

600 or moro

CONCOND

FREDONLI

IVES

MOORES LARLY.

WORDEN.

Red Graps

BRIGHTON.

CACO.

CATAWBA.

DELAWARE.

LUCHLE.

SALEM.

White Grapos

DIAMOND

ELVIRA.

NIAGARA.

PORTLAND

\section{APRICOTS}

ALEXANDER.

BLENHEIM

EARLY GOLDEN

NEWCASTLE EARLY.

SUPERB,

TIITON. Very large, hight

.05
.03

\section{Far Cammercial and Fame Planting}

HARRISON GROWN PLUMS

ABUNDANCE EARLY TO BEAR

ALBION

AMERICAN MIRABELIE.

BLUE DAMSON.

BRADSHAW

BURBANK

GERMAN PRUNE.

GUEII.
HALL.

IMPERIAL EPINEUSE.

IMPERIAL GAGE.

ITALIAN PRUNE

JEFFERSON

RED JUNE.

SANTA ROSA.

SHROPSHIRE DAMSON.

SUPERIOR.

UNDERWOOD.

WICKSON.

WILD GOOSE

\section{DELICIOUS NECTARINES}

BOSTON.

GOWER.

HUNTER. LaTG,

JOHN RIVETA.

STANWICK.

SURE CHOP.

OUR NEW LOW PRICES ON PLUMS, APRICOTS, AND

\section{SOUR CHERRIES}

FOR HOME AND MARKET

DYEHOUSE.

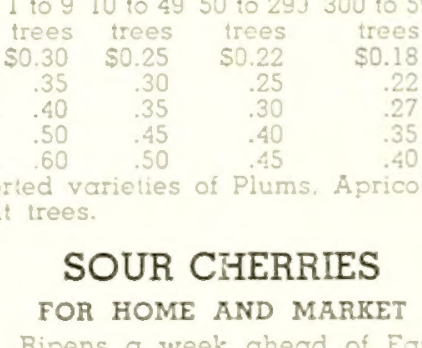

EARLY RICHMOND

ENGLISH MORELLO

MAY DUKE.

MONTMORENCY

OLIVET

RICHMORENCY.

ROYAL DUKE.

PRICES OF HARRISON GROWN SOUR CHERRY TREES

\section{PEARS}

BEURRE BOSC.

BEURRE DANJOU.

CLAPPS FAVORITE.

DUCHESS

KIEFFER

SECKE:

SHELDON. Medium size, flesh slightly coorse, melting, WORDEN SECKEL.

PRICES OF HARRISON GROWN PEAR TREES

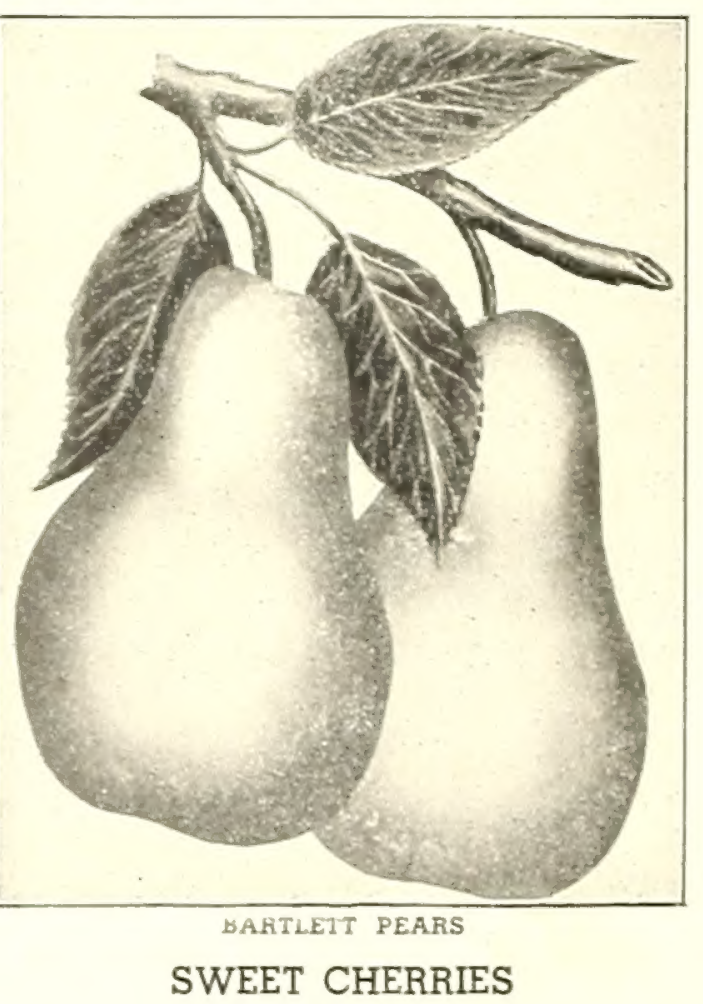

ABUNDANCE. Large yellow, very productive, attractive. BING. Very large dark brown, flesh firm, sweet. Mid BLACK TARTARIAN. Very large, sweet, purplish-black GOLDEN WAX. Large, yellow, fine flavor. Bears bumpLAMBERT. Extra large, sweet, jet black, very popular. LYONS. Large, black, extra early, ripens a week ahead NAPOLEON (Royal Anne). Large, pale yellow, bright SCHMIDT (Schmidt's Bigarrecu). Large, sweet, deep black, tender, fine flavor. Midseason.
WINDSOR. Large, sweet, almost black, fine quality. YELLOW SPANISH. Iarge, sweet, yellow with red tinge. PRICES OF HARRISON GROWN SWEET CHERRY TREES भio 10 to 4950 or more $\begin{array}{lrr}\text { trees } & \text { trees } & \text { trees } \\ \$ 0.30 & \$ 0.25 & \$ 0.20 \\ .40 & 30 & .25\end{array}$ 


\section{Millions of Hi-Quality Asparagus Roots, Strawberry Plants AND SMALL FRUITS FOR GROWERS EVERYWHERE}

PLANT ASARAGGUS FOR

BIG QUICK CASH PROFITS

Within the past few years the popularity of canned and fresh asparagus has increased enormousiy. In fact at the present time there is not enough asparagus acregus growing pays large profits and to those growers MARY WASHINGTON. growing for home use only or for market you canno afford to grow any cther. It is rust resistant and he famous Mary Washington because it is earlier. stalks are larger, more tender and more productive. PRICES OF GENUINE PEDIGREED MARY WASHINGTON ASPARAGUS ROOTS

$\begin{array}{ccccccc}25 & 50 & 100 & 250 & 500 & 1,000 & 5.000 \\ \$ 0.40 & \$ 0.60 & \$ 1.00 & \$ 1.75 & \$ 3.00 & \$ 4.75 & \$ 20.00\end{array}$

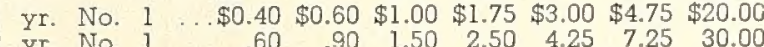
Write for prices on larger quantities. We maintain are in a position to give prompi service on large orders.

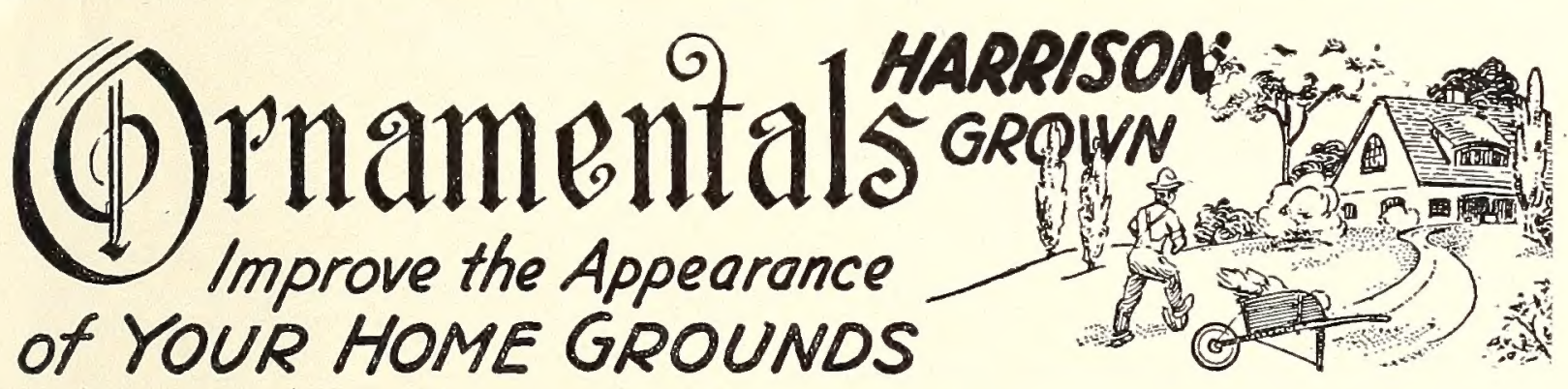

ANTHONY WATERER SPIREA. Dwarf, bright pink flowers

ALTHEA OR ROSE OF SHARON. DOuble red or semidouble white with crimson center.

BUTTERFLY BUSH. Lilac colored flowers in midsummer. DEUTZIA, PRIDE OF ROCHESTER. Double white flowers,

which are slightly tinged with rose, appear in midGOIDEN BELL (Forsythia). Upright grower, yellow flowCOIDEN EEI GOLDEN TWIG DOGWOOD (Cornus stolonifera flaviramea). Dwarf grower, branches are colden in color.

GARLAND or SWEET MOCK ORANGE (Philadelphus alth of white fragrant flowers.

JAPANESE FLOWERING QUINCE (Cydonia japonica) Scarlet flowers in April and May. No doubt one of

JAPANESE BUSH HONEYSUCKLE (Lonicera morrowi). PINK WEIGELA. Delicate pink bell-shaped flowers. PUSSY WILLOW. Shrub or dwarf tree with fur-like catkins during early spring.

RED BRANCHED or CORAL DOGWOOD (Cornus alba sibirica). Bright red bark, white flowers, blue fruit rapid grower; beautiful winter effect.

SPIREA REEVESIANNA. Fast grower, graceful white

TARTARIAN HONEYSUCKLE. Abundance of pink of white fl

TAMARISK AFRICANA. Feathery gray-green foliage: effective near water. Thrives at seashore.

Prices of above shrubs: Big, $11 / 2$ to $2 \mathrm{ft}, 30 \mathrm{c}$ each, 3 for $75 \mathrm{c}, 10$ for $\$ 2.00$; Largest, 2 to $3 \mathrm{ft}, 40 \mathrm{c}$ each, 3 for

\section{SPIREA VAN HOUTTEI}

Beautiful in or out of bloom, and the medium tall broad, compact screen it makes, is protective as well a ornamental. It is always hardy, growing anywhere and will do well in partial shade. Even when trimmed and
kept low, it is a splendid hedge, dense to the ground. 1 to 910 to 4950 to 299300 or more

12 to $18 \mathrm{in.}$

18 to 24 in

2 to $3 \mathrm{ft}$.

plants plants plants plants

HARRISONS

Hil-QUALIV

Remember! Houses Are Cold and Uninviting Uniil The Mar-

vel of Growing Things Transform Them Into Real Homes

HARRISON GROWN

Strawberry Plants SELECTED STRAINS - TRUE TO NAME

This season we will have an unusually fine suppiy
of high grade strawberry plants to offer. These plants are of our own growing and have been doubly inspectanywher

During the two past seasons strawberries have been trawberries for extra quick profits. EARLY: Bellmar, Blakemore, Clermont, Dorsett, Fairfax, Missionary, Premier, Senator Dunlap, Southland. MIDSEASON: Aberdeen, Big Joe, Calskill, Culver, Gibson (Parsons Beauly) Pathfinder.

LATE: Aroma, Big Late, Chesapeake, Gandy, Iupton, New York, Sample, William Belt.

EVERBEARING: Gem, Lucky Strike, Mastodon.

FIRETHORN. A beautiful shrub covered with $\propto$ profuearly spring, followed by 12 in. $35 \mathrm{c}$ each, 2 for $65 \mathrm{c}$; 12 to 15 in. $50 \mathrm{c}$ each, 2 for $90 \mathrm{c}_{i} 15$ to 18 in. $75 \mathrm{c}$ cac

CREPE MYRTLE. Red or pink varieties. 1 to $11 / 2$ it.

HYDRANGEA PEE GEE. Large flowers; at first snowywhite, then changing pink to reddish-bronze in the each

NANDINA DOMESTICA. White flowers followed by red PINK OR BLUE HYDRANGEA.

WEICELA EVA RATHKE. VerY attractive deep carmine.

red flowers, making a very showy shrub. $11 / 2$ to
ft. $40 \mathrm{c}$ each, 2 for $70 \mathrm{c} ; 2$ to $3 \mathrm{ft} .50 \mathrm{c}$ each, 2 for $90 \mathrm{c}$.

THE LOVELIEST LILACS

BELLE DE NANCY.

HUGO KOSTER.

LUDWIG SPAETH. D

MADAME ABEL CHATENAY. Double white.

MARLEYENSIS. Red.

MICHAEL BUCHNER.

PERSIAN PURPLE.

PRESIDENT GREVY. Double bright blue.

ROTHOMAGENSIS. Dark red.

RUBRA DE MARLEY. Light red.

Prices above varieties: 1 to $11 / 2 \mathrm{ft}$. $40 \mathrm{c}$ each, 2 for $70 \mathrm{c}$ 10 for $\$ 3.00$.

\section{AZALEAS}

AZALEA HINODEGIRI. Deep carmine blooms, evergreen type grower.

AZALEA AMOENA. Rose-purple flowers, blooms in early spring and retains its foligge ell year.

AZALEA MACRANTHA. Large, single, salmon-red flow-

PRICES OF HARRISONS' HI-QUALITY AZALEAS

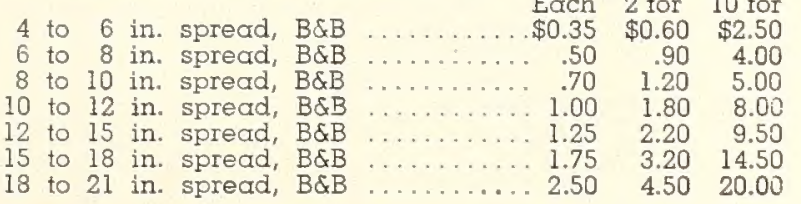
TREES
PRICES RED RASPBERRIES-SELECTED PLANTS

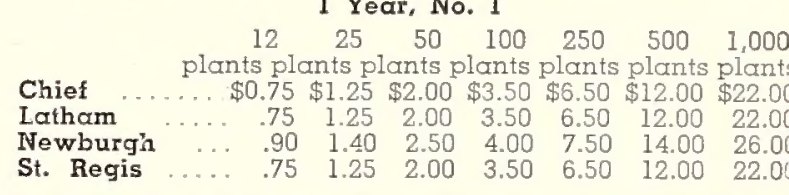

PRICES BLACK RASPBERRIES-SELECTED PLANTS 1 Year, No, 1 Tips

Cumberland

New Logan

DEWBERRIES - 1 YEAR, No. 1 TIPS

Lucretia $\quad \ldots \ldots+\$ 0.45 \$ 0.75 \$ 1.40 \$ 2.50 \$ 4.50 \$ 8.00 \$ 15.00$

BLACKBERRIES SELECTED PLANTS-1 YEAR No.

Alfred

Eldorado

Early Harvest

$$
\text { plants }
$$

The New Mammoth BOYSENBERRY

EASY TO GROW - YIELDS HUGE PROFITS

Prices of New Boysenberry: 15c each, 10 for $\$ 1.20,25$

Hedges Make Beautiful Living Fences

\section{CALIFORNIA PRIVET} (Ligustrum Ovalifolium)

We grow California Privet by the mile. Most popular hedge plant; can be trimmed to any desired shape
For planting long hedges, this is the most economical variety.

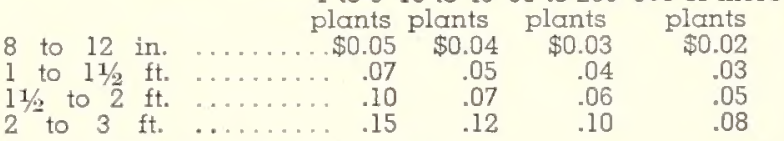

AMUR RIVER NORTH PRIVET (Ligustrum amurense), cardiest of the family with handsome olve
age. Best hedge plant for severe climates.

IBOLIUM PRIVET (Ligustrum ibolium). A cross between Californic and Ibota Privet with beauty of the forme: PRICES OF AMUR RIVER NORTH AND IBOLIUM PRIVET $\begin{array}{lc}\text { plants plants } \\ \$ 0.10 & \$ 0.08\end{array}$

\section{JAPANESE BARBERRY} (Berberis Thunbergi)

Best low dense hedge plant grown. Its abundant, small light green leaves, which turn to rich colors in au tumn, and its wealth of scarlet berries make it ver ing Ornamental and graceful the whole year. Prices per 10 to 4950 to 299300 or more each plant 9 to 12 in. 12 to 15 in. 18 to 24 in.

\section{RED-LEAVED BARBERRY}

(Berberis Thunbergi Atropurpurea)

A highly important introduction among shrubs, gi ing us for the first time a practical easily
of medium height, with good, distinctly This must prove a boon to all types Prices per

each plant.

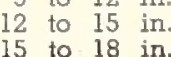

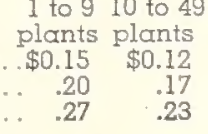




\section{Evergreens for Year Around Beauty}

AMERICAN ARBORVITAE.

CHINESE ARDORVITAE

Prices of cbove varieties:

COMPACT GLOBULAR ARBORVITAE

SPREADING EVERGREENS ANDORRA JUNIPER.

PFITZERS JUNIPEA

SAVIN JUNIPER.

Prices of above varieties:

IRISH JUNIPER.

SWEDISH IUNIPER.

Prices of Irish and Swedish Junizers

ELUE TINT D EVERGREENS MEYERS JUNIPER.

SPINY GREET JUNIPEA.

VIRGINII BLUE JUNIPER

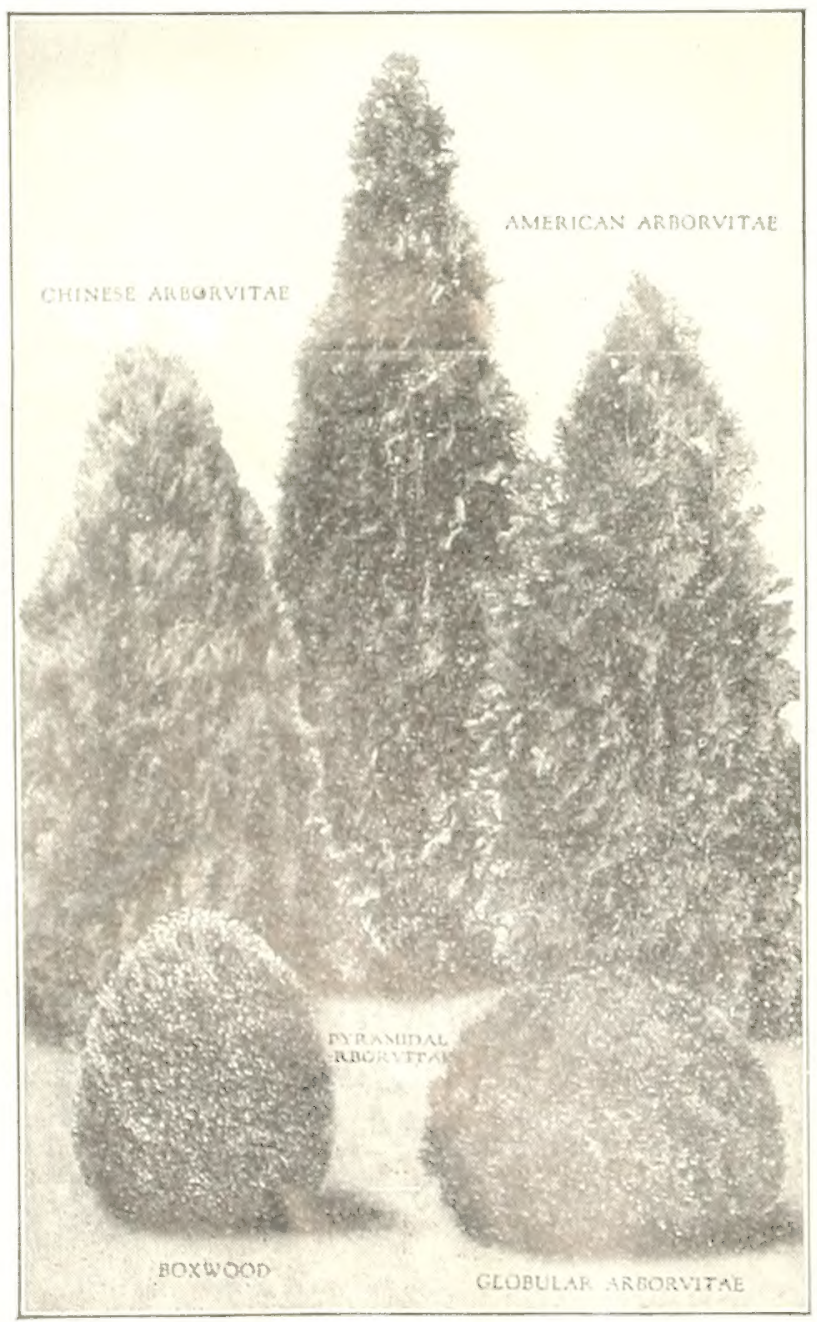

INDIAN CEDAR

JAPANESE CEDAR

COLORADO BLUE SFRUCE

\author{
Piced pungens
}

or planted in groups in tront of darker colored Ever-

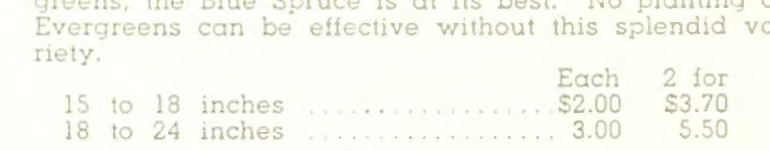

BALSAM FIR (Abies balsamea). A very erect regular

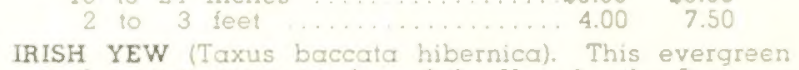

is the aristocratic member of the Yew family. In grows

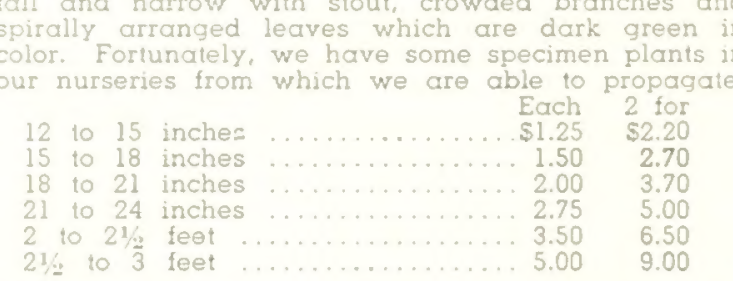

FERN LIKE ARBORVITAE (ThuYa occidentalis filicoides) GEORGE PEABODY ARBORVITAE

luiea). A becutiful variety, the gold mariking diffus-

HINOKI RETINOSPORA (Retinospora oblusa). Compact pyramidal form slightly drooping tips, dark green

JAPANESE SAWARA RETINOSPORA

(Retinospora pisi-

JAPANESE GOLDEN SAWARA RETINOSPORA.

Retinospora, but its color is bright golden.

LEE GOLDEN ARBORVITAE (Thuya occidentalis elegan-

NORWAY SPRUCE

PLUME-LIKE RETINOSPORA. A h

PYRAMIDAL ARBORVITAE

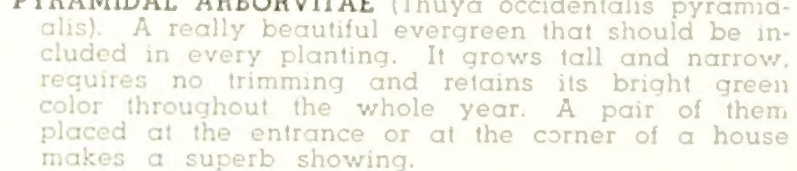

SIBERIAN ARBORVITAE.

THREAD LIKE RETINOSPORA (Retinospora filifera). Ha

TOM THUMB ARBORVITAE

VERVAENE ARBORVITAE

VEITCH'S JAPAITESE RETINOSPORA

Retinospora squar-
feathery and dense.

Prices of above varieties:

$\begin{array}{rr}\text { Each } & 2.105 \\ \$ 1.10 & \$ 2.00 \\ 1.50 & 2.70 \\ 2.00 & 3.70 \\ 3.00 & 5.50\end{array}$

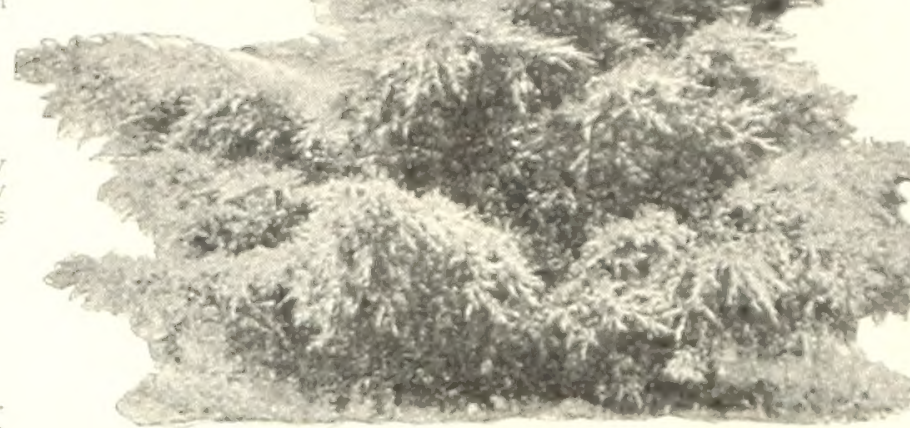

PFITZERS JUNIPER

JAPANESE SPREADING YEW

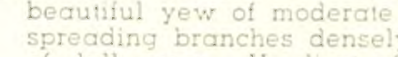

of dull

UPRIGHT ENGLISH YEW

SPREADING ENGLISH YEW
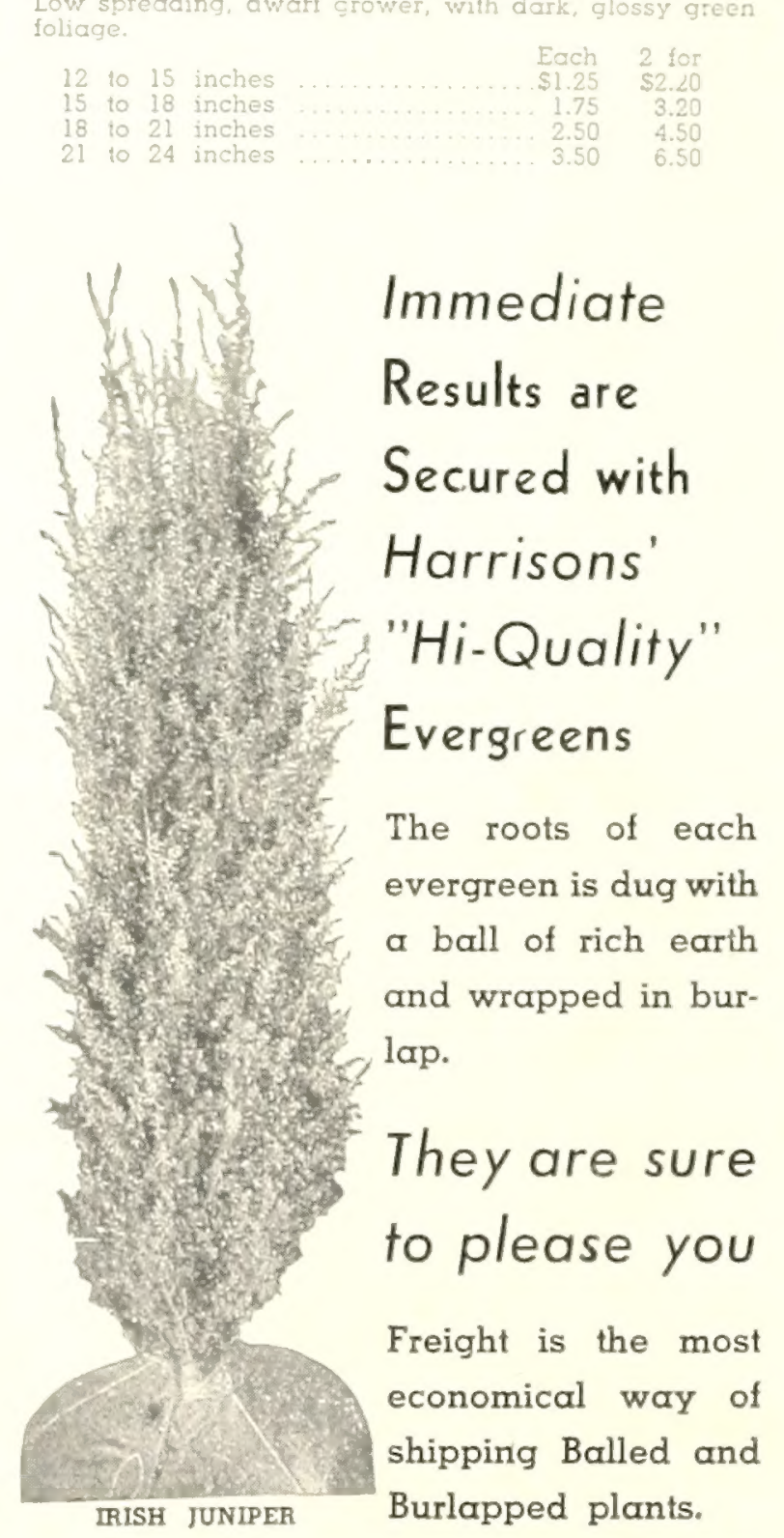

Whisisons

NO HOME IS COMPLETE WITHOUT EVERGREEN PLANTINGS AROUND THE FOUNDATION
Results are

Secured with

Harrisons'

"Hi-Quality"

\section{Evergreens}

The roots of each evergreen is dug with a ball of rich earth and wrapped in burlap.

They are sure to please you

Freight is the most economical way of shipping Balled and Burlapped plants. 


\section{Harrisons'}

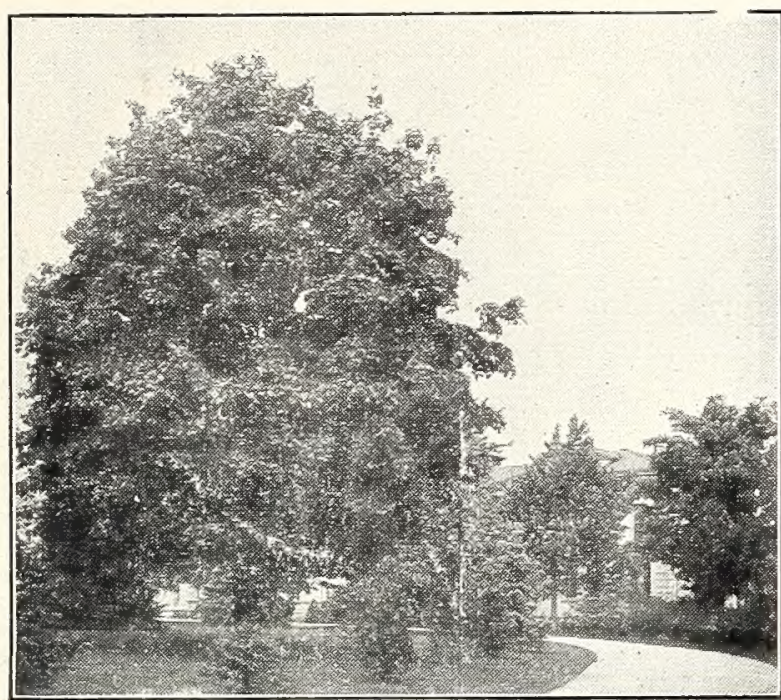

Silver Maple

AMERICA ELM (Ulmus americana). A noble native tree of great size, wide spreading, gracefully curving

long-stemmed flowers in a form like the handsomest American tree for lawns, avenues and parks.

AMERICAN PLANE OR SYCAMORE (Platanus oCcidentalis). A very rapid growing tree for yard or street plantthe winter. Not desirable as the Oriental Plane but CATALPA SPECIOSA. A fast growing large leaved tre ORIENTAL PLANE (Platanus orientalis). A rapid, upright, clean growing tree, long lived, beautiful dense SILVER MAPLES (Acer dasycarpum). Tall, stately tree, rapid grower, graceful, leaves silvery underneath.

Prices of above trees Each 2 for 10 for

6 to 8 feet $\ldots \ldots \ldots \ldots . \$ 1.00 \quad \$ 1.80 \quad \$ 8.00$

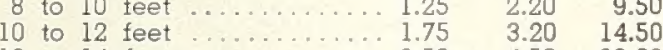

12 to 14 feet

MONEY BACK. In the event that any nursery stock sold by us should prove untrue to name under which it is sold, we hereby agree, on proper proof of such untrueness to name to replace the original order or to refund the purchase price. Except for such liability, and in respect all nursery stock sold by us, we give no warranty, express or im. plied, as to description, quality, productiveness or any other matter.

-HARRISONS' NURSERIES, INC.

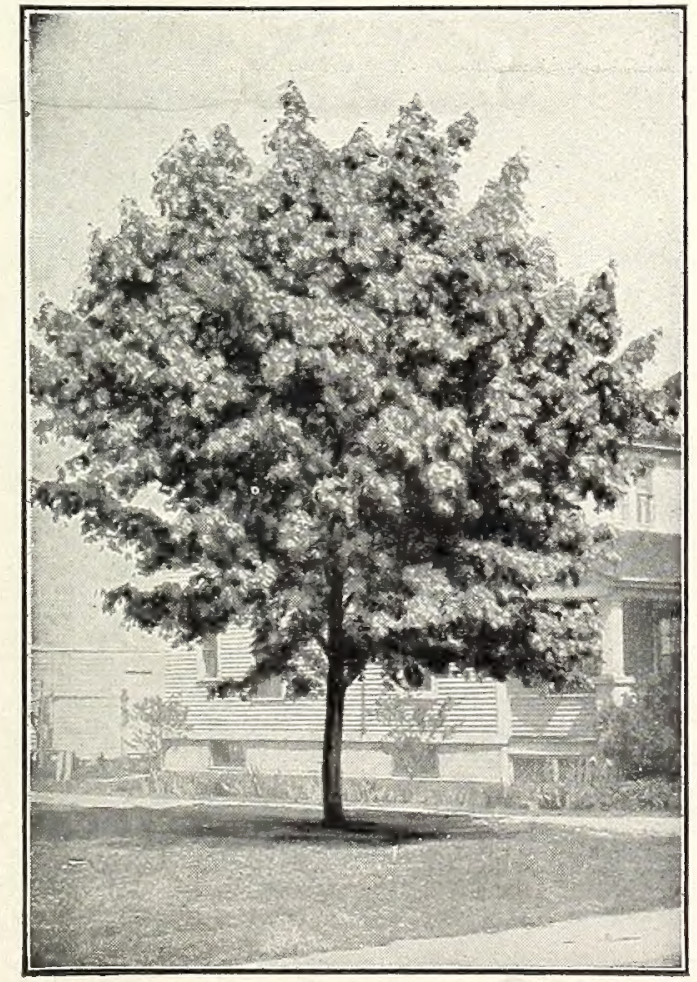

Norway Maple-the most popular shade tree

\section{Give Immediate Results}

NORWAY MAPLES (Acer platanoides). Most popular and best known shade tree. Green fo

SYCAMORE MAPLE (Acer pseudplatanus). Typical map

RED OR SWAMP MAPLE (Acer rubrum). Particula

pleasing

MOLINE ELM. . Grows into a dense conical specimen. CHINESE ELM (Ulmus pumila). This tree

PIN OAK (Quercus palustris). The daintiest and most

Of green foliage; beautiful cutumn effect. A very grace

EUROPEAN LINDEN (Tilia platyphllos). Pyramidal

SWEET GUM (Liquidamber styraciflua). A shapely tree with slender, corky-ridged branches. Leaves are brigh ing tone of crimson color.

Prices of above varieties

8 to 10 feet

10 to 12 feet

CATALPA BUNGEI or Umbrella Tree.

heads without pruning. Hardy.

sides of an entrance or walk

LOMBARDY POPLAR

it is fast growing, distinctly ornamental and beautiful

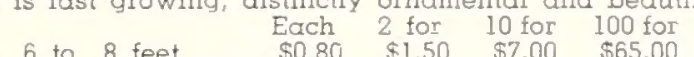

8 to 10 fee
10 to 12 fee

BABYLON WEEPING WILLOW

rapid-growing, hardy tree, thriving in any moist sol.

The willows are valuable and interesting subjects

GOLDEN BARK WEEPING WILLW

growth to the Babylon Weeping Willow except the

bark is of

Prices of above Willows

6 to 8 feet

\section{VINES THAT CLING AND CREEP}

ENGLISH IVY (Hedera helix). The most popular ever green vine; large, deep, green glossy foliage. Excellent BOSTON or JAPANESE IVY (Ampelopsis veitchi).

popular climber, clinging firmly to brick, stone age which turns to cream and gold color in autum
Strong 2 year plants, $30 \mathrm{c}$ each; 2 for $50 \mathrm{c}_{i} 10$ for $\$ 2.3 \mathrm{c}$.
CHINESE WISTERIA. Blue tlower in clusters, during May and June. Strong 2 year plants HALL'S JAPANESE HONEYSUCKLE.

SWEET AUTUMN CLEMATIS

Flowers snowy white: produced in immense quantitie during late summer and autumn.

\section{GARDEN PEONIES
THEY RIVAL THE ROSE}

Prices of all Peonies-Strong 3 to 5 eye divisions $30 \mathrm{c}$ each; 4 for $\$ 1.00 ; 8$ for $\$ 1.75 ; 12$ for $\$ 2.40 ; 50$ o more at $15 c$ each.

AURORE. White: late.

AVALANCHE.

BARONESS SCHROEDER.

DELACHEI.

DUC de WELLINGTON.

CHESS de NEMOURS.

EDULIS SUPERBA.

FESTIVA OUSE.

GERMAINE BIGO

IEANNE D'ARC.

LA PERLE.

MADAME DUCEL.

MADAME de VERNEVILE: Whity mids

MADAME GEISSLER. Rose-pink; late

MADAME LEMOINE.

MARECHAL VAILLANT.

MONS. DUPONT.

PHILOMELE.

PRESIDENT ROOSEVELT.

SUZETTE. ROSe-pink;
UMBELLATA ROSEA.

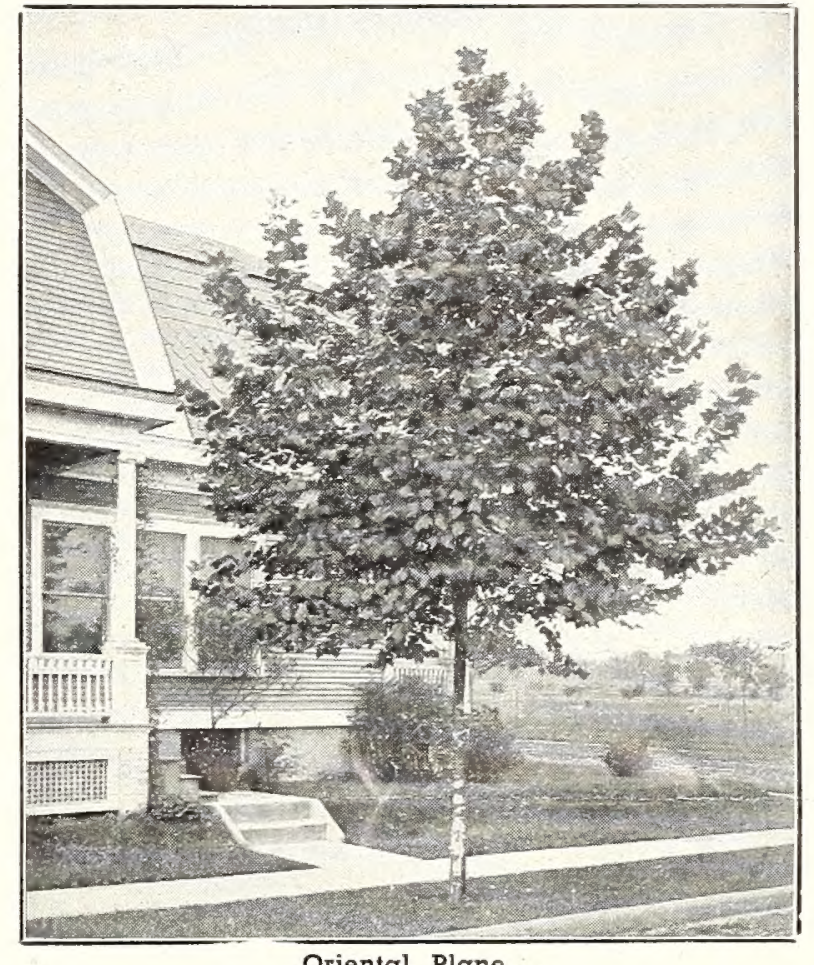

FLOWERING TREES

FLOWERING PEACH.

PURPLE-LEAVED OTHELIO PLUM

Prices of Flowering Peach and Othello Plum $\begin{array}{rr}\text { Each } & 2 \text { for } \\ . \$ 0.40 & \$ 0.70 \\ .50 & .90 \\ 60 & 1.00\end{array}$

BECHTELS FLOWERING CRAB. double. ctly double small roses of deJAPANESE FLOWERING CHERRY-DOUBLE WHITE.

WHITE FLOWERING DOGWOOD Cornus florida). One of

RED FLOWERING DOGWOOD Cornus florida rubral.

WEEPING FLOWERING PEACH.

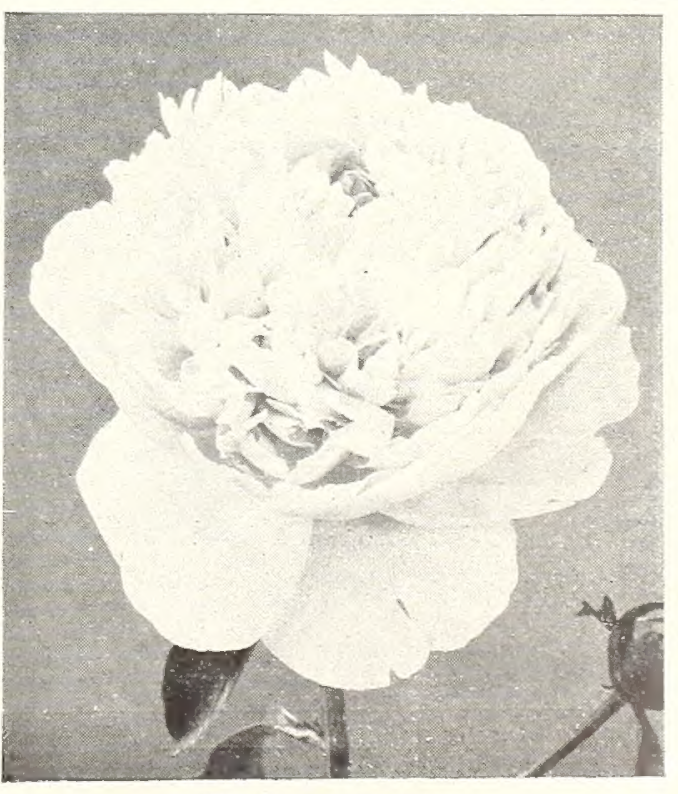

Harrisons' Peonies 


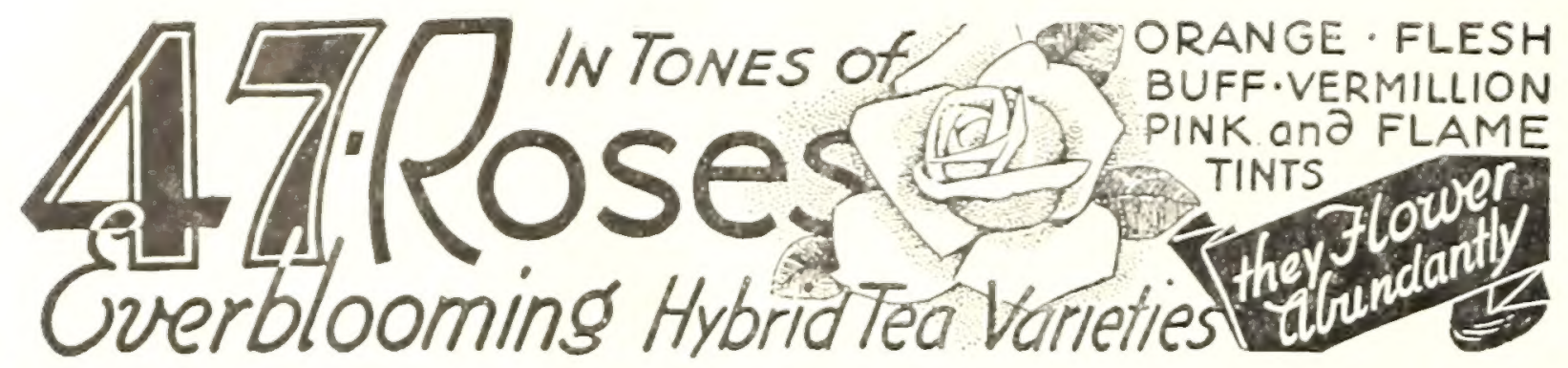

PRICE OF

Aarrisans' Supreme EVERBLOOMING OUTDOOR GROWN HYBRID TEA ROSES

$50 \mathrm{c}$ each, 3 for $\$ 1.35 ; 6$ for $\$ 2.40 ; 12$ for $\$ 4.44 ; 50$ or more $35 \mathrm{c}$ each.

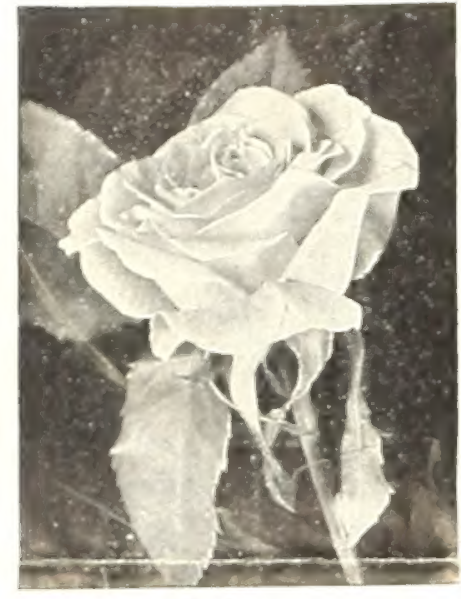

LUXEMBURG.

MRS. W. C. MILLER.

MME. BUTTERFLY.

MRS. CHAS. BELL.

MRS. PIERRE S. DUPONT

MME. EDOUARD HERRIOTT.

MARGARET MCGREDY

MEV. G. A. VAN ROSSEM.

MCGREDY'S SCARLET.

MAS. LOVELL SWISHER.

PINK RADLANCE.

PRES. HERBERT HOOVER.

RAPTURE.

RED RADIANCE.

ROSELANDIA. Bloom ireely,
SOUV. DE CLAUDIUS PERNET.
SOUV. DE GEORGES PERNET.

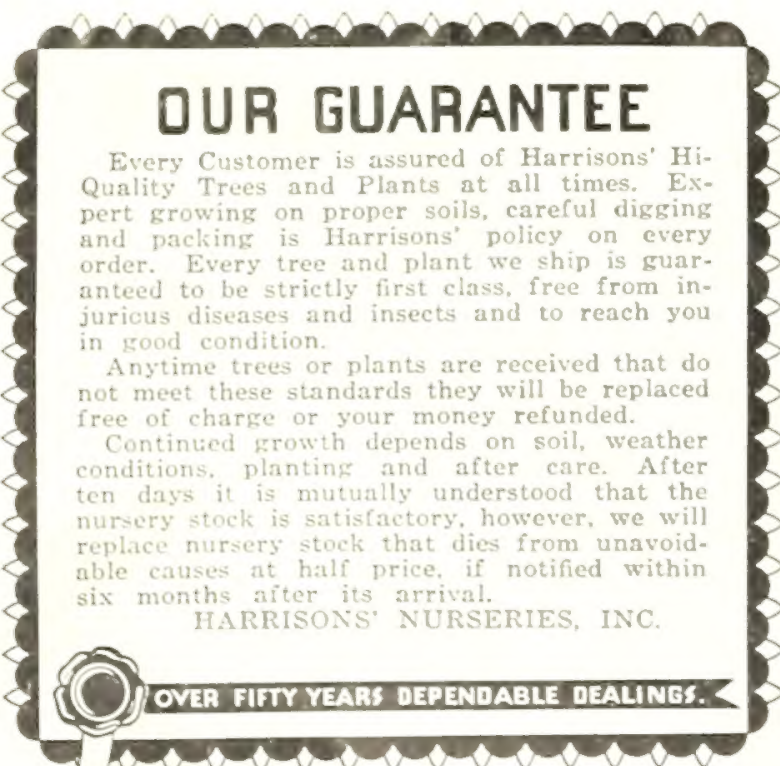

AMI QUINARD. VEI

\section{Harrisons' Supreme Roses}

THEY ARE A SENSATION WHEREVER GROWN

COLUMBIA.

CXLEDONIA.

CRUSADER.

DUCHESS OF WELIINGTON.

E. G. HILL.

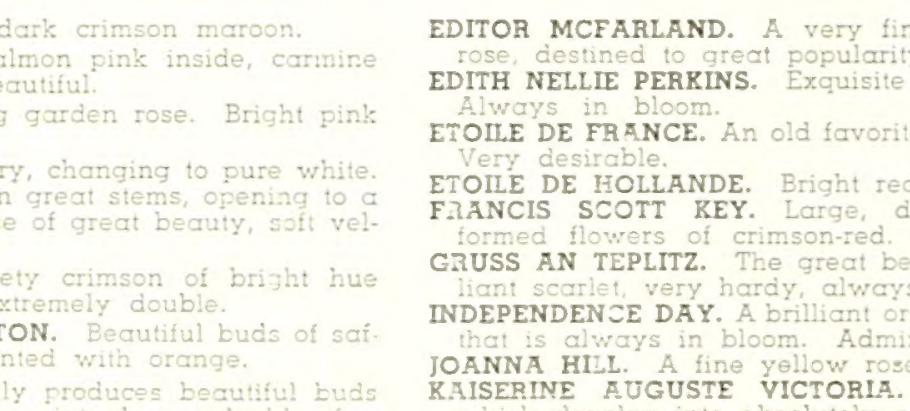

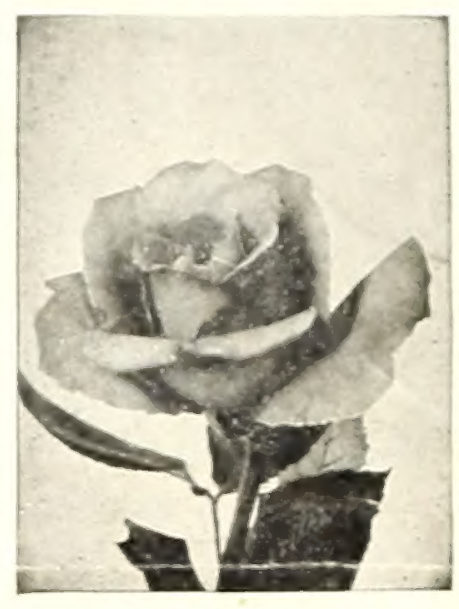

Red Radiance
TALISMAN.

VATERLAND.

HYBRI PERPETUAL OR JUNE ROSES FIELD GROWN PLANTS

5 c each: 3 for $\$ 1.20 ; 6$ for $\$ 2.20 ; 12$ for $\$ 4.00 ; 50$ or FRAU KRRL DRUSCHRI.

GENER II JACQUEMINOT.

MAGNA CHARTA.

MRS. JOHN LAING.

PAUL NEYRON.

ULRICH BRUNNER.

CLIMBING ROSES

FIELD GROWN PLANT

40 e ecec. 3 for $51.10 ; 5$ for $\$ 2.00 ; 12$ for $\$ 3.60$ AMERICAN PIIIAR.

CLIMBING AMERICAN BEAUTY.

DOROTHY PERKINS.

DR. W. VAN FLEET

GARDENIA.

HARRISONS YELLOW.

PRIMROSE

PAUL'S SCARLET CLIMBER.

SCORCHER

BUSH ARBUTUS

BROAD-LEAVED EVERGREENS

JAPANESE HOLLY

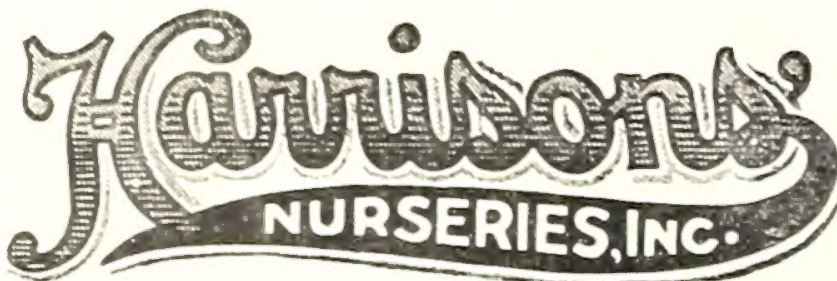

Berlin, Maryland

\section{Broad-Leaved Evergreens}

DWARF ENGLISH BOXWOOD

PRICES OF DWARF ENGLISH BOXWOOD

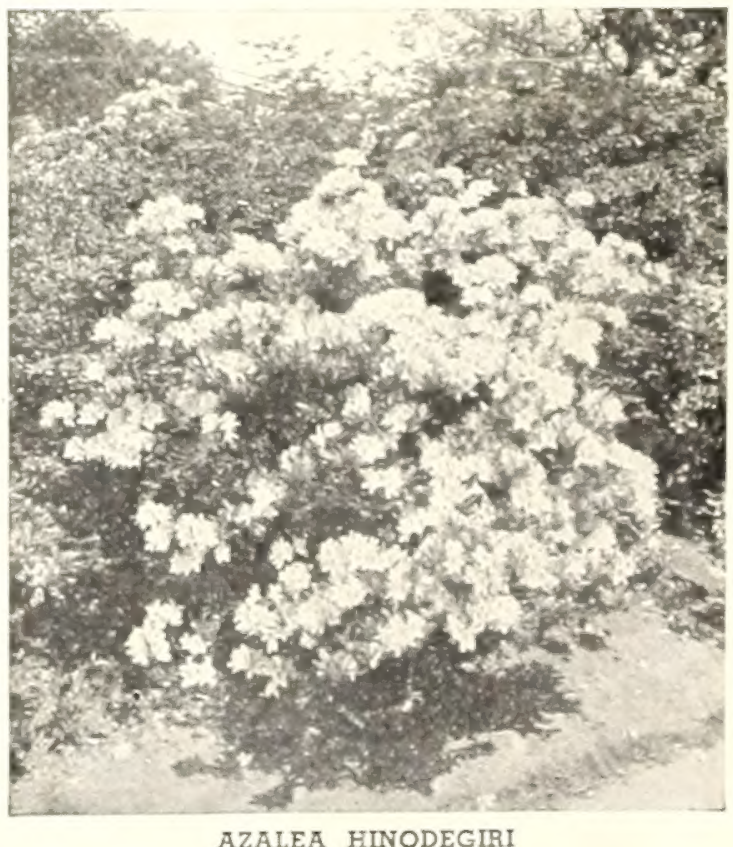

AZALEA HINODEGIRI 